\title{
Strategy for Optimizing the Role of Village Facilitator in the Implementation of Village Fund Policy in South Jawai Sambas District West Kalimantan
}

\author{
Sri Maryuni Pardi* \\ Lecturer of Public Administration, Faculty of Social and Political Science \\ University of Tanjungpura Pontianak, Indonesia
}

\begin{abstract}
This type of research is descriptive with a qualitative approach. The research location is in South Jawai District, Sambas Regency. This research was carried out within 6 (six) months. Data were collected by interview, observation, and documentation methods. The subjects of this study were the Head of the South Jawai Subdistrict, 4 Village Facilitators in the South Jawai District, the Secretary of the South Jawai Sub-District, the Village Heads of Jelu Air and Semperiuk A, and the BPD, and the Community. The results of data collection are then analysed using the SWOT analysis technique. The analysis begins with identifying the internal and internal factors that hinder the implementation of village funds. Then, alternative strategies will be formulated consisting of SO strategy, WO strategy, ST strategy, and WT strategy. The results of the research with SWOT analysis, the results obtained are several alternative strategies to optimize the role of village assistants in implementing the Village Fund policy as follows: a. Evaluate the implementation of the duties of village assistants in the District of South Jawai on a regular/periodic basis. b. Perform clear and specific division of tasks among village assistants including their working areas c. Develop/propose training programs for village governments and communities to encourage or generate creative and innovative ideas for village development. d. Initiate or propose to the village government a budget allocation from village funds to encourage the realization of an independent village. e. Conduct comparative studies to other villages that have made many innovations in village development and community empowerment. f. Always update policies related to village development and empowerment issued by the central government. g. Encouraging the village government to budget for infrastructure development following the portion of the use of village funds. While the suggestions for the village government, in particular, are a. Consistent in the realization of what has been planned in the APBDes and RKP of the village government. b. Encouraging villages to become independent villages.
\end{abstract}

Keywords: Strategy, Optimization, Village Facilitator

DOI: $10.7176 / \mathrm{PPAR} / 11-10-03$

Publication date: December $31^{\text {st }} 2021$

\section{Introduction}

Constitutions No 6 of 2014 concerning Villages regulates the administration of government and development in villages. The law has the aim of realizing and improving the welfare and prosperity of the people in the village so that they are not left behind by the urban areas. The current development paradigm has changed, namely building a country starting from the outermost, poorest and underdeveloped islands, including development that starts from the village. The village is the spearhead of development, if the village has developed and advanced, it will automatically achieve just and sustainable community welfare.

Efforts to carry out village development, the government through the Ministry of Villages, Development of Underdeveloped Regions and Transmigration of the Republic of Indonesia has issued Village Minister Regulation PDTT number 3 of 2015 About Village Facilitator. In the Village Minister Regulation it is stated that the Village together with Village assistants can carry out development in the village to improve the welfare of the community, this is as stated in Article 1 paragraph 6 of the Village Law Number 6 of 2014 concerning Villages.

Further explained in clause 12 Chapter II, the Village Facilitator has the task of assisting the Village in planning, implementing, and monitoring Village development and empowerment of Village communities, assisting the Village in carrying out the management of basic social services, developing Village economic businesses, utilizing natural resources and appropriate technology. use, development of Village infrastructure and empowerment of Village communities, capacity building for Village Government, Village community institutions in terms of development and empowerment of Village communities, organizing in Village community groups, capacity building for Village Community Empowerment Cadres and encouraging the creation of new Village development cadres, assisting the Village in the participatory development of rural areas and coordinating assistance at the sub-district level and facilitating reports on the implementation of assistance by the Camat to the Regional Government Regency/City.

The Government of Sambas Regency as an autonomous region in the province of West Kalimantan has 38 
(thirty-eight) village assistants who assist 193 villages. consists of 19 districts. Of the 19 sub-districts, researchers are interested in the South Jawai District, which consists of 9 villages, with two Local Village Facilitators and one Village Empowerment Facilitator, and one Infrastructure Engineering Village Facilitator.

Under their duties, the village assistant must go down with the village head to plan and carry out various development programs in the village as a form of accountability from the village assistant. Village assistants who work as contract workers need to be evaluated of course. Because many village assistants work not optimally, they work or come to the assisted villages not routinely, but only when they need data for their reporting tasks. Another thing that causes the village assistant's task to be not optimal is because the reach of their work area is very wide, the distance between villages is far and not all villages can be accessed by road. And what is no less important is that the amount of compensation they receive is not commensurate with their enormous task of assisting the village.

By looking at these various problems, village assistants are expected to be able to work optimally according to their duties, especially now that each village receives a fairly large Village Fund from the APBN as a mandate from Village constitutions no. 6 of 2014 concerning Villages. Villages with limited human resources both in terms of ability and experience, of course, will be overwhelmed in managing the Village Fund. For this reason, the active role of village assistants is highly expected by the village government in managing the village funds.

Village assistants deployed to villages in the South Jawai sub-district have gone through a rigorous selection and received various previous education and training provided by the Ministry of Villages Development of Underdeveloped Regions and Transmigration of the Republic of Indonesia, including skills in village financial management. So it is not an exaggeration if the village hopes for the role of village assistants in managing village finances and other development activities.

Village funds received by villages in the South Jawai District in 2020 ranged from Rp. 838,223,000 to the highest Rp. 1,774,290,000. With that much funds, of course, the role of assistant staff is needed in managing and planning, and using it. For any activities from the funds disbursed by the government. However, the implementation of village assistance did not go as expected. This happens because, in the implementation of village assistance, Village Local Facilitators lack the integrity of their duties, responsibilities, and functions and are trapped in routine activities focused on preparing their monthly work reports.

\section{Literature Review}

\section{Implementation of Public Policy}

Implementation is an activity that will determine whether a policy is successful or encounters obstacles and is even rejected by the target group (stakeholders). In line with that, Wahab (2002: 59) argues that policy implementation is not only concerned with the mechanism of elaborating political decisions into routine procedures through bureaucratic channels but more than that which concerns who gets what from a policy. Therefore, policy implementation is the most important aspect of the entire policy process.

Winarno $(2007: 143)$ states that policy implementation is a crucial stage in the public policy process. A policy program must be implemented to have the desired impact or goal. According to Van Meter and Horn (in Purwanto \& Sulistyastuti, 2012: 20) policy implementation Reviews those actions by the public outlined in prior policy decisions (actions taken by the government and private sector, either individually or group that is intended to achieve the objectives and targets of the priority policy. Another opinion is given by Mazmanian and Sabatier (in Widodo, 2007: 88) explains in more detail the process of implementation of the policy by arguing that the implementation is the implementation of policy decisions basic, usually in the form of legislation, but it may be in the form of orders or decisions -important executive decisions or decisions of the judiciary. Moreover Mazmanian and Sabatier said that usually, these decisions identify the problem to be solved, clearly state the goals/targets to be achieved, and various ways to structure/manage the implementation process.

Pressman and Wildavsky (in Purwanto \& Sulistyastuti, 2012: 20) to interpret the implementation of several keywords, which is to run the policy (to carry out), to fulfill the promises as stated in the policy document (to fulfill), to produce an output as stated in the policy document (to produce), to complete the mission that must be realized in the policy objectives (to complete).

Moving on from the opinion above, it can be concluded that policy implementation is an action taken after a policy has been established, by intervening. In other words, implementation is the intervention itself, with the aim that the policy can achieve the goals that have been set. Policy implementation is an activity that is seen after the issuance of a valid direction from a policy, including efforts to manage inputs in producing outputs and outcomes within a certain time for the community.

A program or activity will be able to achieve its objectives if it has gone through the implementation phase based on the applicable provisions or regulations. The new implementation process will begin when the goals and objectives have been set, the activity program has been structured, the funds are ready, and have been channelled to achieve the targets. Policy implementation links the policy objectives and their realization with the results of government activities. 
Based on this understanding, we can understand that the implementation of public policy is the implementation or application of decisions taken by the government in the form of activities carried out either by the government agency or by other stakeholders who are the targets of decisions that have been taken in such a way that the goals has been determined in the decision can have an impact, both positive and negative impacts.

In general, the task of implementation is to develop a relationship structure between the goals of public policies that are set and government actions to realize the goals in the form of policy outcomes. For that, we need a system that is expected, through this system the objectives of the policy can be realized by creating activity programs that lead to the achievement of policy objectives. These programs are developed into projects that must be implemented by the government or the private sector. The purpose of these programs and projects is to bring about changes that are the result of a government policy.

The implementation of a policy often does not run effectively, according to the Edward III policy implementation model (in Winarno, 2002: 125) there are four kinds of factors that affect the effectiveness of policy implementation. These factors or variables are communication, sources, tendencies or behaviours, and bureaucratic structure. The implementation of the policy referred to in this study is the implementation of the village fund policy in villages in the District of South Jawai. Following Government Regulation N0. 22 of 2014 concerning Village Funds.

Village Fund

Government Regulation Number 22 of 2014 concerning Village Funds sourced from the State Revenue Budget (APBN) clause 1 paragraph 2 explains that village funds are funds sourced from the State Budget Revenue and Expenditure allocated for villages transferred through the Regional Budget (APBD) ) Regency/City and used to finance the administration of government, implementation of development, community development and community empowerment.

Then Clause 6 states that the Village Fund is transferred through the Regency/City APBD to be subsequently transferred to the Village Budget (APBDes). Further developments in 2015 were the issuance of Government Regulation Number 60 of 2015 concerning amendments to Government Regulation Number 22 of 2014 concerning Village Funds sourced from the APBN. In this new regulation, the method of providing village funds does not use the weight of population, area, village poverty rate, and village geographical difficulty level (Clause 12), but uses the approach to the number of villages in the district/city area.

Furthermore, Chapter IV regarding the use of Clause 21 explains that

1. Village Funds are used to finance governance, development, community and community empowerment

2. Village funds as referred to in paragraph (1) are prioritized to finance development and community empowerment.

3. Use of village funds as referred to in paragraph (2) implemented under the priority of using village funds as determined by the Minister of Villages, development of underdeveloped villages, and transmigration.

4. Priority of development of village funds as referred to in paragraph (3) is accompanied by general guidelines for the implementation of the use of village funds

Subsequent developments, the government always strives to improve the implementation of village funds, including The last regulation was issued regarding the priority allocation of village funds for 2018 issued by the Ministry of Villages, namely Ministerial Regulation Number 19 of 2017 which regulates in detail the priorities for the use of village funds in 2018. The determination of priorities for the use of village funds is intended as a guideline and reference for the administration of authority, a reference for Regency/City Governments in preparing technical guidelines for the use of village funds, and a reference for Regional and Central Governments in monitoring and evaluating the implementation of the use of village funds.

Chapter 3 clause 4 of the Minister of Village Regulation Number 19 of 2017 states that there are five priority points in the use of village funds, including:

1. Priority for using village funds to finance the implementation of programs and activities in the field of village development and community empowerment

2. Priority for using village funds is prioritized to finance the implementation of programs and activities that cross-sectoral

3. Programs and activities as referred to in paragraph (2) include the fields of superior product activities in the village or rural area, BUMDes or joint BUMDes, ponds, and village sports facilities under village authority.

4. Development of village sports facilities as referred to in paragraph (3) is a business unit managed by BUMDes or BUMDes together.

5. Priority for the use of village funds as referred to in paragraph (1) must be published by the Village Government to village communities in public spaces that can be accessed by village communities. 


\section{Village Fund Policy}

Direct assistance to village funds, hereinafter referred to as Dana Desa (DD), is a fund sourced from the state revenue and expenditure budget designated for villages which are transferred through district/city regional expenditure revenues and used to finance government administration, development implementation, and community empowerment.

1. Village Development Sector

To improve the welfare of rural communities and the quality of human life as well as poverty alleviation, the priority of using village funds is directed at implementing village development programs and activities, including;

a. construction, development, and maintenance of infrastructure or physical facilities and infrastructure for livelihoods, including food security and settlements;

b. construction, development, and maintenance of public health facilities and infrastructure;

c. construction, development, and maintenance of educational, social, and cultural facilities and infrastructure;

d. community economic business development, including construction and maintenance of production and distribution infrastructure; or

e. construction and development of renewable energy infrastructure and environmental conservation activities.

2. Community Empowerment Sector

Priority for the use of village funds for village community empowerment programs and activities is allocated to fund activities aimed at increasing the capacity of citizens or rural communities in entrepreneurial development, increasing income, and expanding the economic scale of individual citizens or community groups and among others:

a. increasing village economic investment through procurement, development, or assistance of production equipment, capital, and capacity building through training and apprenticeship;

b. support for economic activities either developed by BUMDes or Joint BUMDes, as well as by other Village community economic groups and institutions; capacity-building assistance for Village food security programs and activities;

c. community organizing, facilitation, and training of paralegals and legal assistance for the Village community, including the formation of a Village Community Empowerment Cadre (KPMD) and capacity building for Community Study Rooms in the Village (Community Center);

d. promotion and education of public health as well as clean and healthy living movements, including capacity building for management of Posyandu, Poskesdes, Polindes and the availability or functioning of medical/self-medication personnel in the village;

e. support for Forest/Village Beach and Community Forest/Coast management activities;

f. capacity building of community groups for renewable energy and environmental conservation;

g. other fields of economic empowerment activities that are by the analysis of village needs and have been determined in the Village Deliberation.

\section{Village Facilitator}

A goal will not be achieved if it is not supported by the role of the people involved in achieving the goal. The management of village funds is the responsibility of a village head, but in the implementation, it is assisted by village assistants. In Government Regulations (PP) No. 47 of 2015 changes to PP No. 43 of 2014 concerning the implementation of Law No. 6 of 2014 concerning villages, it is stated in clause 129 that what is meant by Professional Assistance Personnel are:

a. Local Village Assistance Personnel on duty in the Village to assist the Village in implementing Village Government, collaborating with the Village, Developing BUMDes, and carrying out-scale development of the local village.

b. Village Local Assistants who work in the District to assist the Village in implementing Village Government, collaborating with the Village, Developing BUMDes, and carrying out local village-scale development.

c. Technical Assistance Personnel assigned in the District area to assist the Village in implementing sectoral programs and activities

d. The task is to increase the capacity of village assistants in the context of implementing village governance, implementing village development, village community development, and village community empowerment.

Furthermore, village assistants are assisted by infrastructure and empowerment experts in carrying out their duties to assist village governments in carrying out development following statutory requirements. (Komaruddin, 2018) 


\section{Status of Village Facilitators}

Implementations of empowerment and assistance to the community is the government's task following the provisions of the Act, namely the Government and local governments empowering Village communities with assistance in stages according to needs, which are technically carried out by the Regency/City Regional Apparatus Work Unit, can be assisted by professional assistants or so-called Village assistants.

Village assistants are assistants, namely to assist the government in carrying out its duties in village development. Village Facilitators are not civil servants or public officials, but only as contract workers who are experts and competent in the field of mentoring and empowerment recruited by the Ministry of Villages, Development of Disadvantaged Regions, and Transmigration of the Republic of Indonesia to be assigned to assist the government in assisting the Village in implementing Constitutions No. 6 The year 2014 was about the implementation and development of the Village (Komaruddin, 2018).

The status of village assistants is contract workers, namely village assistants who work with the government with a work contract that has a predetermined period. Village Facilitators recruited by the Ministry of Villages, Development of Disadvantaged Regions, and Transmigration of the Republic of Indonesia enter into a work contract with the employer (government) through the Commitment Making Officer (PPK). That is, if the contract period expires, the task of a village assistant is declared complete and his obligation to assist the village he is accompanying is void following the provisions of the work contract that was made and agreed upon. The commitment has expired (Komaruddin, 2018).

\section{Task of Village Facilitators}

The village escort task is to accompany and empower the village community in order to carry out development in accordance with the ministry's regulations to carry out the mandate of the Village Act No. 6 of 2014. The regulation of the Ministry explained that the companion Rural Village has seven basic tasks that must be implemented are:

a. Accompanying Villages in planning, implementing and monitoring village development and village community empowerment. The Village Facilitator is assigned to assist the Village government starting from the planning stage, carrying out village consultations with the village community, the village head and the village apparatus concerned, and led by the Village Consultative Body, making development plans and empowerment democratically, creating participatory development, and conducting direct supervision. towards the process of development and empowerment of the village community (Komaruddin, 2018).

b. Assisting the Village in implementing the management of basic social services, developing the Village's economic business, utilizing natural resources and appropriate technology, developing Village infrastructure, and empowering the Village community. Village Facilitators, assisting the government in improving public services, government activity and responsiveness to environmental problems, developing Village Owned Enterprises (BUMDes), introducing technology to the community, empowering communities to improve the quality of human resources, developing infrastructure according to village needs, such as the Village Office, Puskesmas, Village Hall and others.

c. Carry out capacity building for Village Government, Village community institutions in terms of development and empowerment of Village communities. Village assistants assist the village government in carrying out government duties, provide innovative ideas to create new breakthroughs in government, empower and explore community potential and increase community creativity (Komaruddin, 2018).

d. Organizing in village community groups. Village assistants in empowering the community are required to organize village communities, foster community groups such as farmer groups, non-governmental organizations, BUMDes and others.

e. Carry out capacity building for Village Community Empowerment Cadres and encourage the creation of new Village development cadres. Conduct coaching, education and development of village community empowerment cadres through training, seminars, and others.

f. Assisting the Village in the development of rural areas. With the increased creativity of the Village apparatus, the Village community will support the development of rural areas. Community activities through groups or groups are organized expected to increase community participation in building their own village.

g. Coordinate mentoring at the sub-district level and facilitate reports on the implementation of mentoring by the Camat to the Regency/City Government (Komaruddin, 2018).

\section{Research Methods}

In this study, the method used was descriptive and qualitatively analysed. Descriptive method, namely research that seeks to describe a symptom, event, event that is currently happening. This method aims to find factual, in- 
depth data about the existing symptoms regarding the optimization of village assistants in the management of village funds carried out in Jawai Selatan District, Sambas Regency.

The technique of determining the subject/ informant in this study was purposive, namely the determination of subjects based on certain criteria. The subjects in this study were the village assistant elements in the South Jawai District and the agencies involved in the village assistance process, namely: the Secretary of the South Javai Sub-district, the Semperiuk A Village Head and the Jelu Air Village Head, the Semperiuk A Village BPD Chair and Jelu Village water, PDP (Village Empowerment Assistant) on duty at the Sambas Regency level, PDTI (Infrastructure Engineering Village Assistant) in South Jawai District, and PLD (Village Local Assistant) in charge of villages in South Jawai District.

In obtaining data and facts in the field, researchers used data collection techniques: a. Interviews were conducted by researchers to obtain complete and correct data. b. Observations were made by researchers by observing the results of using village funds for both infrastructure development programs and community empowerment programs and seeing the impact on the community. c. Documentation technique by collecting documents related to the Realization Report on the Implementation of APBDes in villages in South Jawai District, especially Jelu Air Village and Semperiuk Village A. By looking at the Realization of APBDes Implementation document, researchers can analysed what programs are planned with the budget from the village fund and analyse its realization. So that it can be seen what programs are realized and which are not.

Testing the credibility of research data is done by triangulation and lengthening observations. There are three forms of triangulation (Sugiyono, 2005:127), namely triangulation of techniques, sources and time, but the researchers used only two, namely triangulation of techniques and sources. The process of data analysis and interpretation is carried out simultaneously when data collection in the field takes place. After getting the information, the analysis was carried out. At this stage of data analysis begins with data reduction, data display and data analysis.

Data analysis used analysis SWOT(Strength, Weakness, Opportunities, Threats) to obtain alternative strategies in optimizing the role of village assistants in implementing village fund policies.

\section{Result and Discussion}

To find out how the role of village facilitators has been optimal or not, it is necessary to look at the duties of the village assistants themselves. In general, there are 4 (four) tasks for village assistants as stated in Constitutions No. 6 of 2014 concerning Villages. The main tasks of village assistants in general are:

a. Assisting the village in planning, implementing and monitoring village development and village community empowerment.

b. Assisting the Village in implementing the management of basic social services, developing the Village's economic business, utilizing natural resources and appropriate technology, developing Village infrastructure, and empowering the Village community.

c. Carry out capacity building for Village Government, Village community institutions in terms of development and empowerment of Village communities.

d. Organizing in Village community groups.

e. Carry out capacity building for Village Community Empowerment Cadres and encourage the creation of new Village development cadres.

f. Assisting the Village in the participatory development of rural areas.

g. Coordinate mentoring at the sub-district level and facilitate reports on the implementation of mentoring by the Camat to the Regency/City Regional Government

With Techniques collection data through interviews, documentation, and observation. From the results of interviews (village heads, BPD, Community Leaders, Village Facilitators) information was obtained that village assistants were in South Jawai District with a total of 4 village assistants overseeing 9 villages as their work area. At the beginning of the assignment, village assistants were not equipped with knowledge and skills related to empowerment and village financial management, especially village funds. This is an irony because it was hoped that the direct village assistants would be able to make a positive contribution, but it turned out that for 9 (nine months of assignment) they had only received training. However, the village assistants continue to contribute to the village even though it is a bit late. Village assistants in the South Java District have played an active role in planning, implementing and monitoring development programs in villages in South Jawai District.

Village facilitators are actively involved in village development planning by actively participating in the Village Musrenbang in the preparation of the Village Government Work Plan (RKP) and also taking an active role in providing inputs related to development priorities. From the results of the documentation search, all villages have made village plans or RKP in accordance with the standards set by the government. All villages have prepared planning documents properly, the problem is at the realization stage. From the data obtained, it can be presented data related to the realization of the budget of several villages that are the object of research.

Jelu Air Village the amount of village funds in 2020 is Rp. 1,239,714,000.00 (one billion two hundred 
thirty-nine million seven hundred and fourteen thousand rupiah). Realization Total revenue is Rp. 1,703,579,073.29. These funds are described in the Jelu Air Village planning in village expenditures for various activities. While the Realization of Expenditures is Rp. 1,623,916.620.00. So when compared with the actual income, there is a surplus of Rp. 80,562,453.29. After investigating the surplus, it was found that there were several plans that were not realized, namely two areas, namely a. the field of Community Empowerment, SubSector of Marine and Fishery, Sub-Sector of Agriculture and Livestock b. The field of population administration management, General Administration Services and population in the Land Sub-Sector. This means that there is no consistency of what has been planned with the realization of the village government. Therefore, the role of village assistants is needed to remind the village government that what has been planned in development can be carried out according to the budget and time that has been set. Moreover, what has not been realized is a program related to community empowerment which is the main task of assisting staff in the village. Of course, this needs to be an important concern for village facilitators. Here the active role of village facilitators in managing village finances is very important, starting from planning to the realization stage. Village assistants are also obliged to oversee the implementation of development planning in the village.

The amount of village funds received by the Sabaran village government in 2020 is Rp. 1,744,290,000.00 (one billion seven hundred forty-four million two hundred and ninety thousand). While the realization of income is Rp. 2,240,672,835.91. This income will be translated in the form of government spending in the village of Sabaran which consists of various activities and programs.

Based on the realization of income and expenditure in the village of Sabaran, there is a surplus of Rp. 39,575,948,78. After being traced to the village of Sabaran. Empowerment sectors that have not been budgeted for are the Cooperatives sub-sector, Small and Medium Enterprises Sub-sector, BPD Capacity Building, Agriculture and Livestock Sub-sector. Meanwhile, the areas that have been planned but cannot be realized are the field of health education and training for health workers and cadres, preparation of reports from the village head, LPPDes, and information to the community and official travel expenses. When compared with Jelu Air village in terms of budget realization, Sabaran village is better because most of what has not been realized is official travel expenses which if you pay attention to each activity there is no need for official travel costs. So what is budgeted for official travel can be diverted to other activities. Empowerment activities are still lacking, especially those related to agriculture and animal husbandry, which have not yet been planned and also for MSMEs. This needs to be a concern for the village head and village assistant staff in preparing the Village RKP for the following year. The two villages that the researcher presents in this discussion are related to the management of village funds as a sample only.

Of the nine villages in the District of Jawai Selatan, the average village has compiled a Village RKP and reports the realization of APBDes every year. Each village has its own advantages and disadvantages according to village conditions, there are villages that plan activities but do not realize them and there are also villages that should plan activities but do not budget for them, especially those related to community empowerment. So it is necessary to improve the understanding of the village government in preparing the village RKP, what are the development priorities in their village, and also the role of the facilitator to remind the village fund utilization in accordance with the proportions. So that there are no errors in the preparation of the village RKP and in its realization.

Other activities carried out apart from managing village finances are village assistants who are also involved in data collection activities for stunting in the village. This is an activity that comes from the Health Office which aims to record children with malnutrition( Stunting) with the aim of taking the right policy in handling it. From these activities, it is clear that the duties of village assistants are not only limited to empowerment and development in the village, but are also actively involved in various basic social service activities carried out by the government in other sectors. Thus, to achieve the success of a government program, inter-sectoral cooperation is needed. This collaboration is very much needed in the implementation of a program, it cannot run alone. Village assistants in the District of South Javai also provide information related to innovations, especially in the field of agriculture, namely how to cultivate land with a touch of technology. But not many people or farmers apply it because it is still patterned with traditional agriculture that relies a lot on nature, so the results are not optimal.

To increase the capacity of the Village Government and Village Community Institutions, the village facilitators have carried out various activities in an effort to increase the capacity of the village government including assistance in the preparation of the Village RKP, assistance in the preparation of development planning drafts infrastructure, while the empowerment of BPD and BUMDES has not been carried out optimally. This is evident in the village government's development planning that has not budgeted for these activities.

Meanwhile, to increase community empowerment cadres in the village, village assistants communicate and coordinate with community groups such as groups of farmers, fishermen and traders in a meeting to explore potentials that can be developed to increase community income. The enormous potential to be developed in South Jawai District at this time is the extraordinary potential of the Bahari Beach. Beaches with white sand and 
waves that are not too big are very potential to be developed into an asset village. In the management of the Bahari beach, it is currently managed by a tourism conscious group. With the management of tourism awareness groups, the current impact can be felt by the community around the coast by opening stalls for visitors. The tourism awareness groups are community empowerment cadres.

The development of rural areas in the southern Jawai sub-district is a marine coastal tourism area that has been managed properly and professionally by tourism-aware groups in the sub-district. However, from the results of the interview, the financial impact for the local village government is not so great, because the money from the beach management goes to the manager, namely the tourism awareness group. But the indirect impact is the construction of road infrastructure to the location of the sea coast which is already good. Another impact is that many traders open stalls around the coast which can indirectly improve their economy.

Meanwhile, to measure the success of village community empowerment according to the Regulation of the Minister of Villages No. 3 of 2015 can be seen from the indicators:

a. The formation of motivators who understand, have affection and are skilled in empowering local communities.

b. The transformation of awareness, commitment, willingness, knowledge, skills and affection is a motivator for government officials in the sub-district/village as well as local community development leaders.

c. Motivated/mobilized by local communities to participate in community development at large.

Based on the results of the analysis conducted by researchers related to the success of village facilitators in community empowerment programs in South Jawai District with reference to the three indicators above, it can be explained as follows:

Empirically in the field that with the existence of Village assistants have been able to provide motivation to the community in the village in South Jawai District, especially related to community empowerment in the health sector. This is evidenced by the presence of posyandu cadres in every village and they are active in efforts to assist the government in increasing awareness in the sector health. The activities they shared with the Puskesmas were providing counselling in the health sector related to a healthy lifestyle, the health of pregnant women and toddlers, nutrition and also related to data collection on stunting (children with malnutrition). These cadres have been able to mobilize the community to be actively involved in empowerment in the field of community health development. In carrying out their duties as empowerment cadres, these cadres always coordinate with traditional leaders and environmental leaders so that it is easy to mobilize the community to actively participate in programs that have been determined by the government.

As for empowerment in the economic sector, the results have not been seen, although several villages have budgeted for various activities in the Village Budget. Especially for BUMDES, the results have not yet shown, BUMDES has not been able to provide an optimal contribution to PADesa for villages that have Bumdes. This of course will also have an impact on the level of welfare economics of the village community concerned. With the existence of Bumdes, it should be able to increase the economic level of the community. So it can be said that the presence of village assistants has not been able to move the awareness of the village government and the community in village economic activities.

\section{Analysis of External and Internal Factors.}

Based on the results of the analysis of external and internal factors, it can be identified strengths, weaknesses, opportunities and threats related to the management of village funds associated with village facilitators. The following are the results of environmental analysis in South Jawai District, Sambas Regency related to Village Fund Management.

\section{Strengths :}

In terms of the strength of the Village government to have a population in the productive age group that dominates the population, with a large number of productive age population groups, this is expected to be able to contribute in the form of ideas and ideas in preparing the APBDes and ADD budget realization reports. In this case, the village government is also supported by the BPD which is always competent in carrying out its duties and functions, one of which is supervising village deliberation activities related to the Village Fund accountability report, in which village deliberation activities related to accountability reports are carried out to find out how much funds are used during development implementation. take place. This is intended so that the use of village funds can then be better utilized so as to encourage community welfare. In addition, one of the strengths of the village government is the existence of village assistants. With village assistants, the village government can consult regarding the direction of village policies, be it development, village government, community development, community empowerment, and emergency conditions (Covid 19). Village assistants play a very important role in regulating and managing village funds in terms of development, so that the funds used in each implementation are development right on target and village funds can be detailed according to the 
needs of each village. For example, in infrastructure development with the Infrastructure Engineering Village Facilitator (PDTi) managing village funds in making a building more efficient, as well as drawings and designs that are made in accordance with village needs and are appropriate, therefore the village government is greatly helped by the Village Facilitator in particular PD-Ti is in the process of developing infrastructure in the village. With the support of this village assistant, the village government is ready to move forward to innovate in improving the welfare of the community in any way by utilizing the amount of ADD received in each village.

\section{Weaknesses}

from the side of the village government, namely the human resources of the village apparatus and the human resources of the village community which can be classified as still low in terms of the level of education. The low human resources of village officials can be seen from their last education, namely that they only graduated from high school or the equivalent. This is very influential on the running of village government which from year to year is increasingly leading to digitalization. This is clearly a weakness for the village government in managing village funds. Lack of community participation, especially the younger generation in every village government activity, is also a weakness in the village government, because the younger generation does not play an active role in building and creating independent villages. In addition, in terms of village assistants, there is also a point of weakness, namely village assistants are less able to take advantage of current technology, such as using laptops, applications and others. Obviously this will hamper reports related to the management of village funds. The lack of a number of village assistants is also a significant weakness in village government where in the South Javai District there are only 2 village assistants covering 9 villages in one sub-district, this makes village assistants have to be extra in assisting each village so that village fund management can be effective.

\section{Opportunities}

Opportunities that can be utilized by the village government are starting to increase community participation in supporting village government policies in development programs. This support from the community is clearly a breath of fresh air for the village government in getting new ideas and ideas related to development proposed by the community. An increasingly active community will also have a positive impact on village fund management evaluation meetings where the community can correct any deficiencies in village development. Opportunities that can be developed by the village government are to be able to make the best use of ADD to create an innovation developed by the community, both from agriculture, creativity that can provide income for villages and communities in a sustainable manner. The existence of BUMDes is a great opportunity for every village in making innovations so that it can create advanced villages that make the economy of the community in the village develop rapidly. Increasing human resources in the community can be a great opportunity for village governments to build and create independent villages and take advantage of young people in the village who have a Diploma or Bachelor's education to be able to participate in village development. In addition, with the village assistant, the village government also gets assistance in the form of direction and guidance in making policy policies related to the management of village funds. For village assistants, high community participation is one of the working partners of village assistants in supervising the performance of the village government in managing village funds.

\section{Threats}

In addition to strengths, weaknesses and opportunities, one of the factors in the analysis in this study is threats. Conditions that can threaten the village in South Jawai District are from the community itself where there are often elements who deliberately create a commotion in the midst of society by spreading issues such as distrust of the community with the village government who considers every village infrastructure development to be there is a village government that corrupts the infrastructure budget, this is very troubling for the village government which always has to calm its people so that they are not provoked by the issue. The breadth of the village coverage and the many things that need to be improved and improved by the village, be it infrastructure, community empowerment is a big threat in the village government determining which parts need and immediately to be given assistance or make an infrastructure, often people assume that the village government is selective. in providing assistance to the community. In addition, there are also government policies or programs that conflict with village government policies. With these conflicting policies, the village government's movement in making innovations is limited.

\section{Matrix SWOT Analysis}

After knowing the strengths, weaknesses, opportunities and threats in optimizing the role of village facilitators in village fund policies in South Jawai District, then a SWOT analysis matrix can be prepared to determine the appropriate alternative strategy in order to optimize the role of village facilitators. The SWOT Analysis matrix can be seen in Table 1. below: 
Table 1.

Matrix SWOT Analysis

Strategy for Optimizing Village Facilitators in Implementing Policies

Village Fund In Jawai Selatan District

\begin{tabular}{|c|c|c|}
\hline & Opportunity (Opportunities): & Threats (Threats/Challenges): \\
\hline SWOT Analysis & $\begin{array}{l}\text { a. of Village Development } \\
\text { Innovations } \\
\text { b. Become independent } \\
\text { village }\end{array}$ & $\begin{array}{l}\text { a. Very large area } \\
\text { b. infrastructure Roadis not } \\
\text { good } \\
\text { c. Central government } \\
\text { policy that is rapidly } \\
\text { changing }\end{array}$ \\
\hline Strength: & Strategy SO & Strategy WO \\
\hline $\begin{array}{ll}\text { a. Very large population } \\
\text { Large } \\
\text { b. Village Fund } \\
\text { c. Community } \\
\text { d. Participation High } \\
\text { e. Village Government } \\
\text { e. Support Support from } \\
\text { BPD } \\
\text { f. Village Facilitator } \\
\text { g. Availability } \\
\text { BUMDESproposes }\end{array}$ & $\begin{array}{l}\text { a. Initiates/Allocation of } \\
\text { funds from the village } \\
\text { government } \\
\text { independent villages } \\
\text { accompanied by village } \\
\text { facilitators } \\
\text { b. Conduct comparative } \\
\text { studies/benmarching to } \\
\text { villages that have village } \\
\text { development } \\
\text { innovations/empowerment }\end{array}$ & 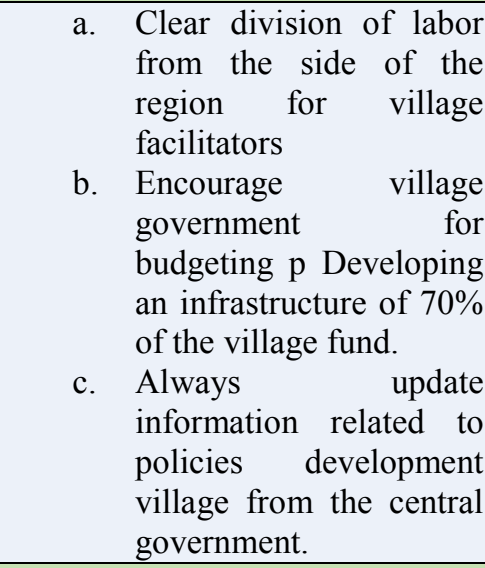 \\
\hline Weaknesses (Weaknesses): & Strategy WO & Strategy WT \\
\hline $\begin{array}{l}\text { a. Limited Number of Village } \\
\text { Facilitators } \\
\text { b. Utilization of technology } \\
\text { that is not maximized } \\
\text { c. skills Technical Are still } \\
\text { limited } \\
\text { d. Level of community } \\
\text { education is still low } \\
\text { e. Level of village/community } \\
\text { innovation is low }\end{array}$ & $\begin{array}{l}\text { a. Specific and clear division } \\
\text { of work both in terms of } \\
\text { tasks and work areas. } \\
\text { b. Develop a training } \\
\text { program for the } \\
\text { community to generate } \\
\text { creativity/creative and } \\
\text { innovative ideas for their } \\
\text { village. }\end{array}$ & $\begin{array}{l}\text { a. Conduct an evaluation } \\
\text { of the implementation of } \\
\text { the work. } \\
\text { b. Making a scale of } \\
\text { development priorities } \\
\text { in villages in the sub- } \\
\text { district of south java in } \\
\text { the following year }\end{array}$ \\
\hline
\end{tabular}

Source ; Data processed by Researchers, 2021

\section{Conclusion}

Based on the results of the discussion of the results of field research that researchers have conducted in South Jawai District, Sambas Regency related to optimizing the role of village assistants in managing village funds, several conclusions can be drawn:

a. Internal Factor Analysis

Based on analysis factors internally related to optimizing village facilitators In the management of village funds, strengths and weaknesses can be identified. Its strengths are the support from the village government, the BPD, and the local community, the support of a fairly large village fund, and the support of the village assistants who have knowledge and skills in the field of empowerment. While the limitations/weaknesses are the limited number of village assistants to assist 9 villages with very wide geographical conditions and access to poor infrastructure and access between villages mostly by river transportation.

b. External Factor Analysis

Based on an analysis of the external environment that shows how the village can continue to exist or be sustainable in carrying out its duties as village assistants. The opportunities for village assistants in carrying out development in the village are the opening of innovations that can be carried out by village assistants in village development, the opening of opportunities for villages to become independent 
villages with the support of existing village resources. Meanwhile, the challenges are the village area which is quite large, the infrastructure road isn't good and the government policies are constantly changing related to village development and empowerment policies.

c. Alternative Strategies for Optimizing Village Facilitators in South Jawai District are as follows:

1. Evaluating the implementation of village assistant duties in the South Jawai District.

2. Carry out a clear and specific division of tasks between village assistants, including their working areas.

3. Develop/propose training programs for village governments and communities to encourage or generate creative and innovative ideas for village development.

4. Initiate or propose to the village government a budget allocation from village funds to encourage the realization of an independent village.

5. Conduct comparative studies/benchmarking to other villages that have made many innovations in village development and community empowerment.

6. Always Update policies related to village development and empowerment issued by the central government.

7. Encourage the village government to budget for infrastructure development following the portion of the use of village funds.

\section{Recommendations}

Based on the analysis of the discussion and conclusions above, recommendations can be given, namely:

1. Optimizing the role of assistants in the village to assist in development planning and village community empowerment programs.

2. Consistent in the realization of what has been planned in the APBDes

3. Pouring creative and innovative ideas in helping the village government to carry out development in the village and empowering the village community and village government RKP and encouraging the village government to realize an independent village.

\section{REFERENCES}

Abidin, Said Zainal. 2004. Kebijakan Publik. Jakarta: Pancur Siwah

Ali, M. A., 2014, Analisis Optimalisasi Pelayanan Konsumen Berdasarkan Teori Antrian pada Kaltimgps.Com di Samarinda, Ejournal Ilmu Administrasi Bisnis. Harahap, E.St,

Bungin, Burhan. 2003. Analisis Data Penelitian Kualitatif, Pemanfaatan Filosofi dan Metodologi kearah Penguasaan Model Aplikasi. Jakarta: Raja Grafindo Persada.

Dunn, William. N. 2002. Analisia Kebijaksanaan Publik. Yogyakarta: Hanindita. Gaffar, Afan. 1998. Publik Policy: State Of The Disipline, Models and Proces. Yogyakarta:

Pasca Sarjana Universitas Gajah Mada.

Gito, Sudarmono, Indriyo dan Agus, Mulyono. 1997. Prinsip-Prinsip Dasar Manajemen. Yogyakarta: BPEF.

Islamy, M. Irfan. 2001. Prinsip-Prinsip Perumusan Kebijakan Negara. Jakarta: Buni Aksara.

Jones, O Charles. 2000. Pengantar Kebijakan Publik, Terjemahan Riky Istamto. Jakarta: Raja Grafio Persada.

Komaruddin. 2018. Peran Pendamping Desa Dalam Pemberdayaan Masyarakat (Studi Di Pekon Paku

Kecamatan Kelumbayan Kabupaten Tanggamus). Gelar Sarjana Sosial (S.Sos) Dalam Bidang Ilmu Ushuluddin. Fakultas Ushuluddin Universitas Islam Negeri Raden Intan. Lampung

Mazmania, Daniel H. And Paul A. Sabatier. 1998. Implementation and Public Policy. New York: Harper Collins. Miles, Matthew B dan Huberman A, Michael. 1992. Analisis Data Kualitatif. Jakarta: Universitas Indonesia.

Moleong, Lexy J.M.A. 2007. Metodologi Penelitian Kualitatif. Bandung: Remaja Rosdakarya.

Nugroho, D Riant. 2003. Kebijakan Publik, Formulasi, Implementasi dan Evaluasi. Jakarta: Gramedia.

Purwodarminto, WJS,1988. Kamus Besar Bahasa. Indonesia, Balai Pustaka, Jakarta. Purmanto, Agus Erwan \& Sulistyastuti, Ratih, Dyah. 2012. Implementasi Kebijakan

Publik: Konsep dan Aplikasinya di Indonesia. Yogyakarta: Gava Media.

Ripley, Randal B, dan Franklin, Grace A. 1984. Policy Implementation and Bureaucracy. Chicago: The Dorsey Press.

Rusli, Budiman. 2003. Kebijakan Publik, Membangun Pelayanan Publik yang Responsif. Bandung: Hakim Publising.

Subarsono, AG. 2005. Analisis Kebijakan Publik: Konsep, Teori dan Aplikasi. Yogyakarta: Pustaka Pelajar.

Sunggono, Bambang. 1994. Hukum dan Kebijaksanaan Publik. Jakarta: Sinar Grafika. Sugiono, 2013. Metode

Penelitian Kuantitatif, Kualitatif dan R\&D, Alfabeta,

CV .Bandung.

Soekanto, Soeryono, 2017. Sosiologi : Suatu Pengantar, Rajawali, Press Jakarta.

Sumaryadi, I Nyoman. 2005. Evektivitas Implementasi Kebijakan Otonomi Daerah. Jakarta: Citra Utama. 
Tachjan. 2006. Implementasi kebijakan publik. Bandung: AIPI \& Puslit KP2W Lemlit Unpad.

Wahab,, A Solichin. 2002. Pengantar Analisis Kebijakan Negara. Jakarta: Reneka Cipta.

Wibawa, Samodra. 2000. Kebijaksanaan Publik Proses dan Analisis. Jakarta: Intermedia.

Widodo, Joko. 2008. Analisis Kebijakan Publik, Konsep dan Aplikasi. Analisis Proses Kebijakan Publik. Jakarta: Bayu Media.

Winarno. 2002. Teori dan Proses Kebijakan Publik. Yogyakarta: Pressindo. 